DOI: $10.38136 /$ jgon.790143

\title{
Tekrarlayan Fetal Kayıpları Olan Bir Hastada Düşükle İlişkili Mozaik Double Trizomi
}

\section{Mosaic Double Trisomy Associated with Miscarriage in a Patient with Recurrent Fetal Losses}
Canan UNAL
(1) Orcid ID: 0000-0003-0881-2831
Murat CAGAN
(D) Orcid ID: 0000-0003-0629-4401
Gizem Urel DEMIR
(1) Orcid ID: 0000-0002-9928-3236
Erdem FADILOGLU
(1) Orcid ID: 0000-0001-7953-2517
Fatma Sema ANAR
(1) Orcid ID: 0000-0002-3913-0238
Gülen Eda UTINE
(1) Orcid ID: 0000-0001-6577-5542
M. Sinan BEKSAC
(1) Orcid ID: 0000-0001-6362-787X

${ }^{1}$ Division of Perinatology, Department of Obstetrics and Gynecology, Hacettepe University, Ankara, Turkey

2 Department of Pediatric Genetics, Hacettepe University, Ankara, Turkey

\section{öz}

Daha önce 5 gebelik kaybı olan 25 yaşındaki gebe kliniğimize başvurdu. Mevcut gebeliği 9 . gestasyonel hafta ile uyumluydu ve fetal kardiyak aktivite yoktu, bu nedenle gebelik termine edildi. GTG bantlama tekniği kullanılarak kürtaj materyalinin sitogenetik analizi sonucu 48, XY, + 12, + 15 [5] / 46, XY [25] bulundu. Literatürde bu karyotipe sahip mozaik double trizomi (DT) bildirilmediği görüldü. Trombofili paneli sonucunda heterozigot MTHFR C677T polimorfizmi saptandı. Sonuç olarak, MTHFR polimorfizmlerinin DT gibi nadir kromozomal anormalliklerle ilişkili olabileceği düşünüldü.

Anahtar Kelimeler: Double trizomi, mozaik patern, MTHFR polimorfizm, tekrarlayan gebelik kayıpları, sitogenetik analiz

\section{INTRODUCTION}

Chromosomal abnormalities have been observed in approximately $50 \%$ of first trimester miscarriages. Single trisomies constitute the vast majority of chromosomal aberrations associated with early pregnancy losses, whilst double trisomy (DT) is a rare entity (1). DT was first reported in 1959 by Ford et al. in a patient with extra copies of chromosome $\mathrm{X}$ and chromosome 21 (2). The frequencies of DT ranging from $0.21 \%$ to $2.8 \%$ have been reported in several studies (3-5). Further, DT may arise in a mosaic state, which was demonstrated in roughly $5 \%$ of entire trisomies (6).

Herein, we reported on a pregnancy complicated by DT and also discussed coexisting MTHFR C677T polymorphism as a risk factor. To the best of our knowledge, this is the first case with mosaic DT involving chromosomes 12 and 15.

\section{ABSTRACT}

A 25-year-old pregnant woman with a history of five previous miscarriages was admitted to our clinic. Her current pregnancy was also terminated at 9 weeks of gestation due to the lack of fetal cardiac activity. Cytogenetic analysis of abortion material using GTG banding technique revealed 48,XY,+12,+15[5]/46,XY[25] karyotype. Mosaic double trisomy with this karyotype has not been reported in the literature. Thrombophilia evaluation revealed that she had heterozygous MTHFR C677T polymorphism. In conclusion, we may deduce that MTHFR polymorphisms might be related to rare chromosomal abnormalities, such as DT.

Key words: Cytogenetic analysis, double trisomy, mosaicism, MTHFR polymorphism, recurrent pregnancy loss

\section{CASE}

A 25-year-old pregnant woman with a history of five previous miscarriages was admitted to our clinic. She had undergone abortion in her first pregnancy at 14 weeks gestation due to anhydramnios. Her second pregnancy had ended in a miscarriage at 19 weeks gestation due to premature rupture of membranes. Both of her first two pregnancies showed normal karyotypes. Her third pregnancy was noted to be an ectopic pregnancy leading to abortion at 5 weeks gestation. Afterwards, she experienced two more miscarriages at 7 weeks of gestation due to the lack of fetal cardiac activity which could not been investigated for chromosomal abnormalities.

Her current pregnancy was also terminated at 9 weeks of gestation due to the lack of fetal cardiac activity. Cytogenetic analysis of abortion material using GTG banding technique revealed $48, X Y,+12,+15[5] / 46, X Y[25]$ karyotype. (7) Both parents were 
found to have normal karyotypes and physical examinations showed no obvious abnormalities. Thrombophilia evaluation revealed that she had heterozygous MTHFR C677T polymorphism.

\section{DISCUSSION}

$\mathrm{DT}$ is a rare condition associated with spontaneous miscarriage although, approximately $60 \%$ of cytogenetically abnormal spontaneous abortions arise from trisomies, involving mostly single trisomies (5). DT have been documented most commonly in miscarriages related to trisomies involving chromosomes 8,13 , $15,16,18,21$, and sex chromosomes $(3,5,8)$. Likewise, single trisomies frequently involve those chromosomes (5).

Mosaic trisomies constitute approximately $5 \%$ of total trisomies (6). Mosaicism involving the non-acrocentric chromosomes has been more frequently reported compared with the mosaicism involving acrocentric chromosomes $(6,9)$. Hassold reported the frequency of acrocentric chromosomes in complete trisomies as at least $39 \%$, whereas no mosaic karyotype concerning acrocentric chromosomes was present (6). In our case, we observed a mosaic karyotype involving both acrocentric and non-acrocentric chromosomes. Also we excluded the probability of maternal cell contamination due to lack of metaphases with XX chromosomes in our case (10). Complete DT with aforementioned chromosomal constitution is well-known, however, no mosaic cases have been reported previously (8).

Furthermore, maternal age of the present case is inconsistent with the literature. Despite the strict relationship between advanced maternal age and aneuploidy, no relationship between maternal age and mosaicism has been shown (11). Previous studies regarding the association between DT and maternal age have revealed the mean maternal age as varied between 34.5 and $39.7(3,4)$. Moreover, there are several reports demonstrating the similar relevance between advanced maternal age and $\mathrm{DT}(5,8,12)$.

DNA methylation is a crucial epigenetic modification of the genome which is involved in regulating many cellular processes such as embryonic development and chromosomal stability (13). MTHFR is an enzyme that participates in the methionine metabolism. Methionine is the precursor of S-adenosyl methionine (SAM) which is the main methyl donor for DNA. MTHFR polymorphisms inhibit the conversion of the dietary folate into an active form, thus inducing an increase of homocysteine and a decrease of the amounts of SAM. Because of the low SAM levels, DNA hypomethylation occurs which may be accompanied by congenital and chromosomal abnormalities (14). In a study of the patients with Turner sydrome, a close association between MTHFR A1298C polymorphism, notably genotype 1298CC, with chromosomal abnormalities has been revealed (15). Additionally, MTHFR A1298C polymorphism was significantly associated with an increased risk of spontaneous abortions due to chromosomal aneuploidy (16). Previous studies also linked MTHFR 677 polymorphisms with spontaneous abortions more than MTHFR 1298 polymorphisms (17). In conclusion, due to the close association of spontaneous abortions with chromosomal abnormalities, we may deduce that MTHFR polymorphisms might be related to rare chromosomal abnormalities, such as DT causing adverse pregnancy outcomes including early pregnancy losses.

\section{REFERENCES}

1. Hassold T, Chen N, Funkhouser J, Jooss T, Manuel B, Matsuura J, et al. A cytogenetic study of 1000 spontaneous abortions. Annals of human genetics. 1980;44(2):151-64.

2. Ford $\mathrm{C}$, Jones $\mathrm{K}$, Miller $\mathrm{O}$, Mittwoch $U$, Penrose $\mathrm{L}$, Ridler $\mathrm{M}$, et al. The chromosomes in a patient showing both mongolism and the Klinefelter syndrome. The Lancet. 1959;273(7075):709-10.

3. Diego-Alvarez D, Ramos-Corrales C, Garcia-Hoyos M, Bustamante-Aragones A, Cantalapiedra D, Diaz-Recasens J, et al. Double trisomy in spontaneous miscarriages: cytogenetic and molecular approach. Human Reproduction. 2005;21(4):958-66.

4. Li QY, Tsukishiro S, Nakagawa C, Tanemura M, SugiuraIOgasawara M, Suzumori K, et al. Parental origin and cell stage of nonddisjunction of double trisomy in spontaneous abortion. Congenital anomalies. 2005;45(1):21-5.

5. Reddy K. Double trisomy in spontaneous abortions. Human genetics. 1997;101(3):339-45.

6. Hassold T. Mosaic trisomies in human spontaneous abortions. Human genetics. 1982;61(1):31-5.

7. Ütine GE, Çelik T, Alanay Y, Alikasifoglu M, Boduroglu $\mathrm{K}$, Tunçbilek $\mathrm{E}$, et al. Subtelomeric rearrangements in mental retardation: Hacettepe University experience in 130 patients. The Turkish journal of pediatrics. 2009;51(3):199.

8. Micale M, Insko J, Ebrahim SA, Adeyinka A, Runke C, Van Dyke DL. Double trisomy revisited-a multicenter experience. Prenatal Diagnosis: Published in Affiliation With the International Society for Prenatal Diagnosis. 2010;30(2):173-6.

9. Stene J, Warburton D. Evidence for smaller probabilities for trisomic mosaicism for acrocentric than for nonacrocentric chromosomes. American journal of human genetics. 
1981;33(3):484.

10. Eiben B, Schubbe I, Borgmann S, Hansmann I. Rapid cytogenetic diagnosis of early spontaneous abortions. The Lancet. 1986;327(8492):1273-4.

11. Taylor TH, Gitlin SA, Patrick JL, Crain JL, Wilson JM, Griffin DK. The origin, mechanisms, incidence and clinical consequences of chromosomal mosaicism in humans. Human reproduction update. 2014;20(4):571-81.

12. Hassold T, Chiu D. Maternal age-specific rates of numerical chromosome abnormalities with special reference to trisomy. Human genetics. 1985;70(1):11-7.

13. Robertson KD. DNA methylation and human disease. Nature Reviews Genetics. 2005;6(8):597.

14. Enciso M, Sarasa J, Xanthopoulou L, Bristow S, Bowles M, Fragouli E, et al. Polymorphisms in the MTHFR gene influence embryo viability and the incidence of aneuploidy. Human genetics. 2016;135(5):555-68.
15. Oliveira KCd, Bianco B, Verreschi IT, Guedes AD, Galera BB, Galera MF, et al. Prevalence of the polymorphism MTHFR A1298C and not MTHFR C677T is related to chromosomal aneuploidy in Brazilian Turner Syndrome patients. Arquivos Brasileiros de Endocrinologia \& Metabologia. 2008;52(8):137481.

16. Kim SY, Park SY, Choi JW, Kim DJ, Lee SY, Lim JH, et al. Association between MTHFR 1298A>C polymorphism and spontaneous abortion with fetal chromosomal aneuploidy. American Journal of Reproductive Immunology. 2011;66(4):252-8.

17. Turgal M, Gumruk F, Karaagaoglu E, Beksac MS. Methylenetetrahydrofolate reductase polymorphisms and pregnancy outcome. Geburtshilfe und Frauenheilkunde. 2018;78(09):871-8. 